Regular Article

pISSN: 2287-2396, eISSN: 2287-240X

Journal of Forest Science

Vol. 29, No. 3, pp. 181-193, August, 2013

http://dx.doi.org/10.7747/JFS.2013.29.3.181

\title{
Coping with Climate Change by Using Indigenous Knowledge of Ethnic Communities from in and around Lawachara National Park of Bangladesh
}

Sayma Akhter ${ }^{1,2, *}$, Farzana Raihan ${ }^{1}$, Md. Shawkat Islam Sohel ${ }^{1}$, Md. Abu Syed ${ }^{3}$, Suman Kanti Das ${ }^{4}$ and Mohammed Alamgir ${ }^{5,6}$

${ }^{1}$ Department of Forestry and Environmental Science, Shahjalal University of Science and Technology, Sylhet-3114, Bangladesh

${ }^{2}$ School of Environment, Natural resources and Geography, Bangor University, Bangor LL57 2UW, United Kingdom

${ }^{3}$ Bangladesh Center for Advanced Studies, Dhaka-1212, Bangladesh

${ }^{4}$ Department of Statistics, Shahjalal University of Science and Technology, Sylhet-3114, Bangladesh

${ }^{5}$ School of Earth and Environmental Sciences, James Cook University, Cairns, 4870 Queensland, Australia

${ }^{6}$ Institute of Forestry and Environmental Sciences, University of Chittagong, Chittagong-4331, Bangladesh

\begin{abstract}
Climate change is considered to be one of the most serious threats and its impact is felt by the most vulnerable world's poorest countries including Bangladesh. In particular, ethnic communities, whose livelihoods depend on the use of natural resources, are likely to bear the brunt of adverse impacts. A case study was conducted in a fragile ecosystem of Lawachara national park of Bangladesh, to know the indigenous knowledge of the ethnic communities, how they adapt with the climate change impact by using indigenous knowledge. They use various IK to protect their crops from climate change impact. Thus, government should design policies which will be helpful to make them more resilience to face climate change impact.
\end{abstract}

Key Words: adaptation, indigenous knowledge, climate change, ethnic communities, Bangladesh

\section{Introduction}

Climate change is one of the most pressing environmental concerns of the 21 st century. The risks associated with these changes are real and already happening in many systems and sectors essential for human livelihood. Developing countries are the most vulnerable to these risks (Boer 2009), because of their generally low adaptive capacities (IPCC 2007). Adaptation to climate change did not receive much attention in the beginning of climate change re- search and focus was found more on mitigation and impacts (Kates 2000) but adaptation has recently been covered more extensively (IPCC 2007) due to its increasing capacity building for the community people during difficulties. Bangladesh is the most vulnerable country in the world to climate change impact (Gentleman and Ahmed 2007; Pender 2008; Boer 2009). Poor, marginalized and disadvantaged people in rural areas of Bangladesh, whose livelihoods primarily depend on natural resources and climate-sensitive sectors such as agriculture, forestry and fish-

Received: February 22, 2013. Revised: July 12, 2013. Accepted: July 22, 2013.

Corresponding author: Sayma Akhter

School of Environment, Natural resources and Geography, Bangor University, Bangor LL57 2UW, United Kingdom

Tel: 447448830982, Fax: 447448830982, E-mail: sayma_sust@yahoo.com 
eries, are more vulnerable to climate change (Dahal 2006; Raut 2006; Regmi and Adhikari 2007) as most of the forest dwellers engage in agriculture and rely on natural resources, for their livelihoods, food and water (Sapkota et al. 2006; Selvaraju et al. 2006). They have few livelihood options and therefore, vulnerable to adverse climatic conditions that affect their crops, animals, water sources and other natural resources (Regmi and Adhikari 2007). Thus the problem of climate change impacts needs to be addressed from various angles in order to achieve effective mitigation and adaptation. One such angle is how indigenous knowledge (IK) can contribute to monitoring and adaptation to the changing climate. Studies on the contribution of IK to climate change research are few (Shaw et al. 2008; Gbetibouo 2009; Green and Raygorodetsky 2010; Green et al. 2009; Orlove et al. 2010). Most of the study had been conducted Africa and Australian region focusing mainly early warning system and drought risk. Although Bangladesh is vulnerable to climate change, very few studies was conducted to highlight the contribution of IK of ethnic community in facing climate change challenge. Maleya Foundation (2009) conducted a study on ethnic community of Chittagong hill tract region (southern part) of Bangladesh, to know their adaptation strategies. Like southern part, northeastern part of Bangladesh is also threatened by climate change and very few studies were found on this issue about this area. From extensive literature survey, only one study was found in Lawachara national park situated in northeastern part of Bangladesh which was conducted by Nobel (2009) where core issue was community based climate change adaptation through community based agroforestry. But Lawachara national park is blessed by a diversified ethnic community and they have different ecosystem and livelihood acclivities. So, it is very essential to find out how ethnic community's livelihood and ecosystem is affected by climate change and how they use their knowledge to adjust with climate change. Furthermore, the contributions of IK (Indigenous Knowledge) to understanding and interpreting ecological processes and for use in environmental and social impact assessments is widely acknowledged (Olsson et al. 2004). These contributions can be related to climate change mitigation and adaptation activities like reforestation can absorb carbon while crop diversification of home garden can give food se- curity which may reduce livelihood problem caused by climate change impact. Taking this view ahead, this study analyses the IK (Indigenous Knowledge) of the selected ethnic communities of in and around LNP (Lawachara National Park), Bangladesh, to explore the climate change scenario, impact on ethnic communities and their coping strategies.

\section{Materials and Methods}

\section{Brief description of research site}

This research was conducted in and around the Lawachara National Park which is in the north eastern region of Bangladesh which is one of the fragile forest ecosystem vulnerable to changing climate. Lawachara National Park ( LNP) is located in $\left(24^{\circ} 30^{\prime}-24^{\circ} 32^{\prime} \mathrm{N}\right.$ and $\left.91^{\circ} 37^{\prime}-91^{\circ} 39^{\prime} \mathrm{E}\right)$. The park was founded in 1996 with a total forest area of 1,250 ha. It forms part of West Bhanugach Reserved Forests, which is under the area of Sylhet Forest Division. LNP is a mega biodiversity region with many floral species. Hoolock Gibbon and Capped Langur are keystone species located in the park (NSP 2006). The park also serves as the home of several indigenous communities. Members of the Khasia, Manipuri, Garo and Tripura indigenous groups reside within and around the forests. These communities depend on the forest resources for their livelihood opportunities (NSP 2006). The park is very well connected by rail, air, and road transportation systems. Lawachara National Park has 26 villages in and around it, and approximately 4,000 households reside in those villages (Mollah and Kunda 2004). Two indigenous punjis (villages) composed of Khasia people, are located inside and adjacent area of the park. Lawachara Punji named after Lawachara stream has 23 households. The other village, Magurchara Punji, consists of 60 households. The villages are on hillocks. Forest Department personnel settled people in these villages in the 1950 s to assist with forestry related activities. The Munipuri tribes are found in the village near to LNP named Baligaon, which has more than $75 \mathrm{HH}$ (personal communication), the Garo tribes are found in the village named Fulbari and Gila chora, which is in the north-west corner consisting 20 and $40 \mathrm{HHs}$ respectively. There is another village, called Dolubari, a long established Tripura (locally called Tipra) settlement of $60 \mathrm{HH}$ at the 
hill foot flat at the south-west boundary of the park.

\section{Methods}

The study was carried out in 2010 by selecting the study area purposively due to the availability of different ethnic community ecological zone. There were four ethnic communities available in and around LNP (Lawachara National Park). Those are Khasia, Garo, Monipuri and Tripura. There were two Khasia punji, one Monipuri para, one Garo bosti and one Tripura para (Fig. 1). Among 26 villages, only four villages were selected considering community type by stratified random sampling method. Before, data collection a week long initial field visit was carried out. The main objective of that visit was to become familiar with the study area such as geographical situation and social structure. It helped to identify socio-economic and bio-physical conditions of community. For the study semi-structured questionnaire survey, key informant interview and focus group discussions (FGD) has been conducted for the collection of data. Interview with the key informants (Fig. 2A) was taken to identify perception and attitude about the problem. Elder people, the king / the head- man of the community were considered as the key informant for interview. Moreover the eco-tour guides were also considered as the key informant for the study because they are mostly from different ethnic communities and have immense knowledge about the issues considered important for the research. In this research, face-to-face interview was applied for information collection. Key informant inter-

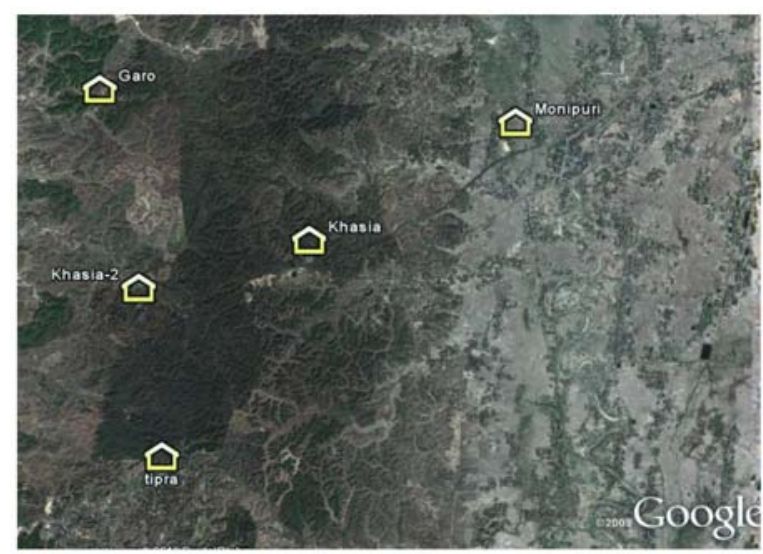

Fig. 1. Map of the study area showing the village of the ethnic people.

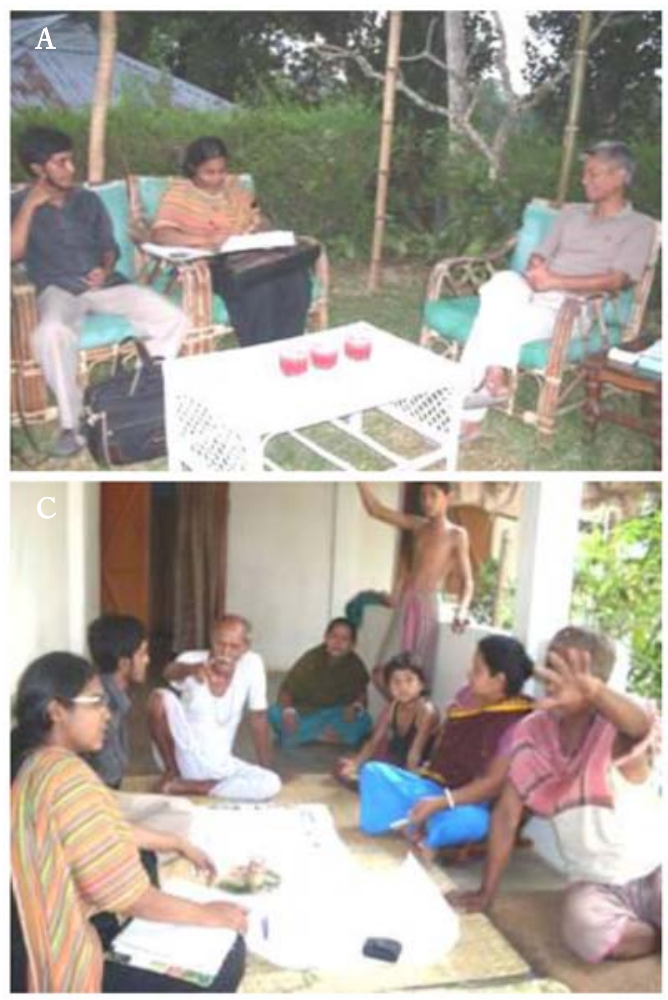

Fig. 2. (A) Key Informant Interview with Khasia King. (B) Household survey with a Tipra woman. (C) Focus group discussion with Monipuri community people.

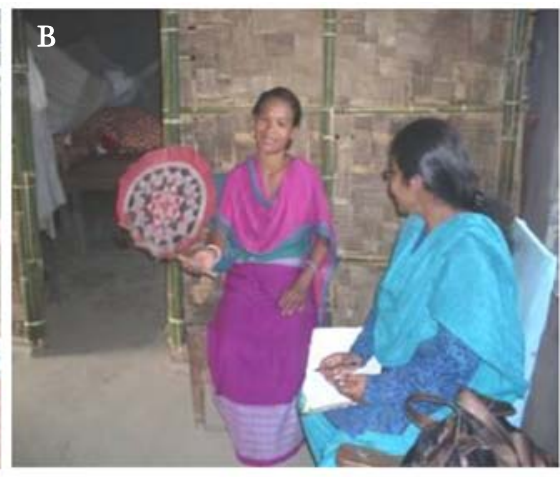




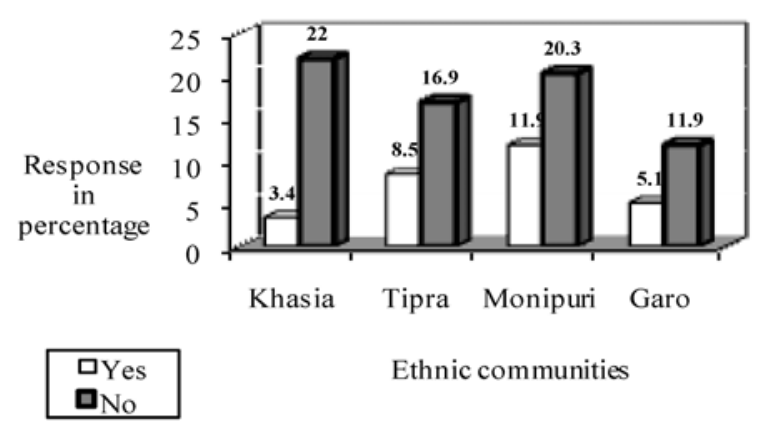

Fig. 3. Ethnic communities knowledge about climate change.

views were taken from four respondents (a single person from a community). Focused group discussions (FGDs) were held in the communities for two purpose. Those are -situation analysis and potentiality analysis. Situation analysis has been done to identify current observed climate changes and impacts of such changes particularly on local livelihoods. Potentiality analysis has been done, to know the resources available in the community and the extents to which these resources help the people live to cope with the impacts of changing climate. Based on the objective of the research, four FGDs were conducted in four ethnic communities. Equal number of participants (both male and female) was selected for FGDs (Fig. 2C) and a total of six participants ( 3 male and 3 female) were selected for each FGD considering their age. Total 235 Households were found in the study area and 59 households were surveyed with $25 \%$ sampling intensity (Fig. 2B). After collection of field data, data were analyzed using MS EXCEL and SPSS both qualitative and quantitative analysis has been done for the study. In the present study factor analysis was done to identify the climate hazards that have pronounced effect on the production of key crops of the ethnic communities living in and around Lawachara National Park of Bangladesh (Fig. 1, 2).

\section{Results}

\section{Community knowledge and perception about cli- mate change scenario}

The knowledge and awareness about the climate change in the study area was very low. Communities did not understand climate change, but they have experienced changes in

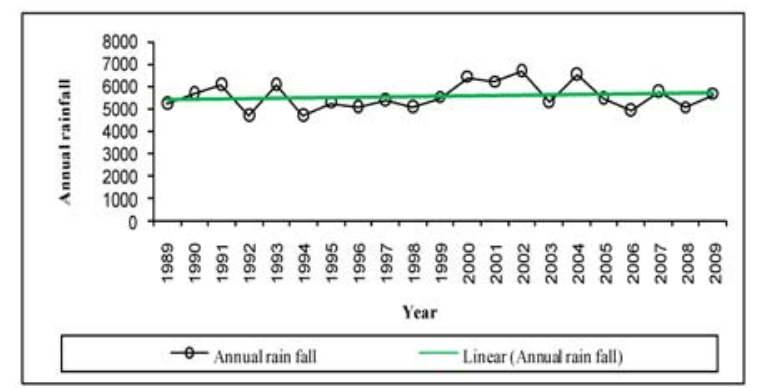

Fig. 4. Average rainfall of LNP from 1989 to 2009.

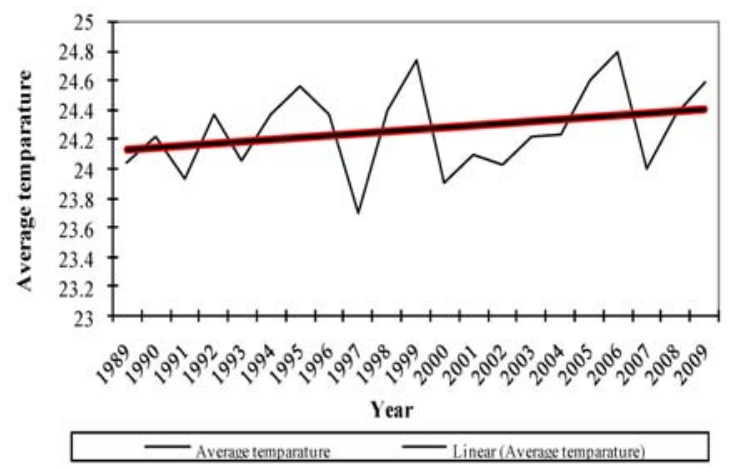

Fig. 5. Average temperature of LNP from 1989 to 2009.

terms of temperature and rainfall. It was found that among the four ethnic communities Monipuri community have more knowledge (11.90\%) than three other community and Khasia community have the least knowledge (3.40\%) about climate change (Fig. 3). Monipuri (58\%), khasia and Tipra (53\%), Garo (60\%) observed changing pattern (Erratic) of rainfall. At the same time, majority perceived the temperature has been increased. Total annual rainfall and temperature data was collected from BMD (Bangladesh Meteorological Department) of Shrimangal station which showed, the total annual rainfall and temperature was increased from 1989-2009 in Lawachara National Park of Bangladesh (Fig. 4, 5).

\section{Observed climate change impact on production of key crops and Indigenous adaptation options}

Ethnic communities have different farming practices. In the study area, betel leaf cultivation is the main crop for Khasia community though Garo people also practice this in their home garden but not as commercial purpose. Besides, lemon and pineapple cultivation is the major farming prac- 
tices of Tipra community and agriculture is the major farming practice for Monipuri community. During the last few years, their major productions of key crops were highly affected by climate change. Adaptation to climate change refers to minimizing the negative consequences of climate change on peoples' lives, as well as enhancing the possible positive consequences. Adaptation options are many. To adapt with the changing climate indigenous people use various techniques.

\section{Climate change impact on production of betel leaf and indigenous adaptation options}

According to Khasia and Garo people Betel leaf production is affected by low rainfall; drought; heavy fog and cold; and PCA (Principle Component Analysis) shows they belongs to factor-1 which is named as precipitation are related hazards (Table 1). They faced loss in betel leaf production due to heavy fog and cold. It has been hound that betel leaf becomes red colored which causes 30-40\% loss. They usually harvest the affected leaves early (before the leaves are fully matured) and sell them at a lower price which causes income loss (Table 2). Due to scarcity of water the production is hampered and mulching is done to conserve soil moistures (Table 2). There are mainly two types of diseases found those are- leaf spot (Utram) and root decaying (Ukhram). Due to utram disesase infected leaf spot occur and leaves dry then the vine dies. This disease occurs due to intense high rainfall and humidity. Besides, Ukhram disease also occurs due to high rainfall. The rainfall data of

Table 1. Climate change hazards on the production Betel leaf

\begin{tabular}{lccc}
\hline \multirow{2}{*}{ Climate hazards } & \multicolumn{3}{c}{ Component } \\
\cline { 2 - 4 } & Factor 1 & Factor 2 & Factor 3 \\
\hline High rainfall & & 0.823 & \\
Low rainfall & 0.929 & & \\
Drought & 0.868 & & 0.714 \\
Natural disaster & & & 0.573 \\
Soil erosion & & & \\
Heavy fog and cold & 0.785 & 26.36 & 17.47 \\
Total variances (\%) & 37.39 & 1.46 & 1.03 \\
Eigen value & 1.91 & & \\
\hline
\end{tabular}

KMO value $=0.51$ and only factor loading $\geq 0.50$ has been shown in the tale.
Meteorological department from (1989 to 2009) also shows increasing trend of rainfall in that station (Fig. 4). To improve the fertility of the soil they recently provide manure (cow-dung). However, an interesting practice was also found in Khasia village which is after death, the bodies of Khasia people were burned and they keep the ash (the residues after complete burning the dead body) into a pot and buried in the farm land while planting new crops. They belief is that, if the soul of the dead enters the farm land, soil fertility and production of betel leaf will increases. To minimize the loss of production, Khasia people are being adopted with diversification of crop production (Table 2). Integrated homestead forestry systems are a suitable pathway for diversification of crop production. Mangifera indica, Artocarpus heterophyllus, Musa sapientum, Carica papaya, Artocarpus chaplasha and other fruit species has become major species on the farms of the Khasia and Garo community and contribute significantly to food security by providing products year round. Diversification of crops also fulfills the demand of timber and fuel wood. Interesting thing is that for diversification of crops they prefer indigenous plant species (Table 1).

\section{Climate change impact on production of pineapple and adaptation options}

Jhum cultivation was the ancient practice of Tipra community but now their practice mainly pineapple and lemon in Lawachara National Park. The principal component analysis shows that (Table 3 ) in factor -1 , increasing temperature (0.933) and soil erosion (0.706) were the major climatic hazards which affect the production of pineapple. The production periods of pineapple are twice a year (One in May-June and another in November-December). Due to increasing temperature and erratic rainfall the production rate of the productive year $\left(2^{\text {nd }}, 3^{\text {rd }}\right.$ and $4^{\text {th }}$ year $)$ is reduced as in summer season when the extreme temperature causes sunburn of the fruits moreover as the rainfall amount in summer season increased this also cause fruits to rot quickly. During autumn season the production is hampered due to increasing temperature as the autumn temperature also increased. To save the production from high temperature farmers cover the fruits with banana leaves during high sunshine intensity (Table 2). Farmers also use rotten leaves of pineapple as manure to increase soil fertility (Table 


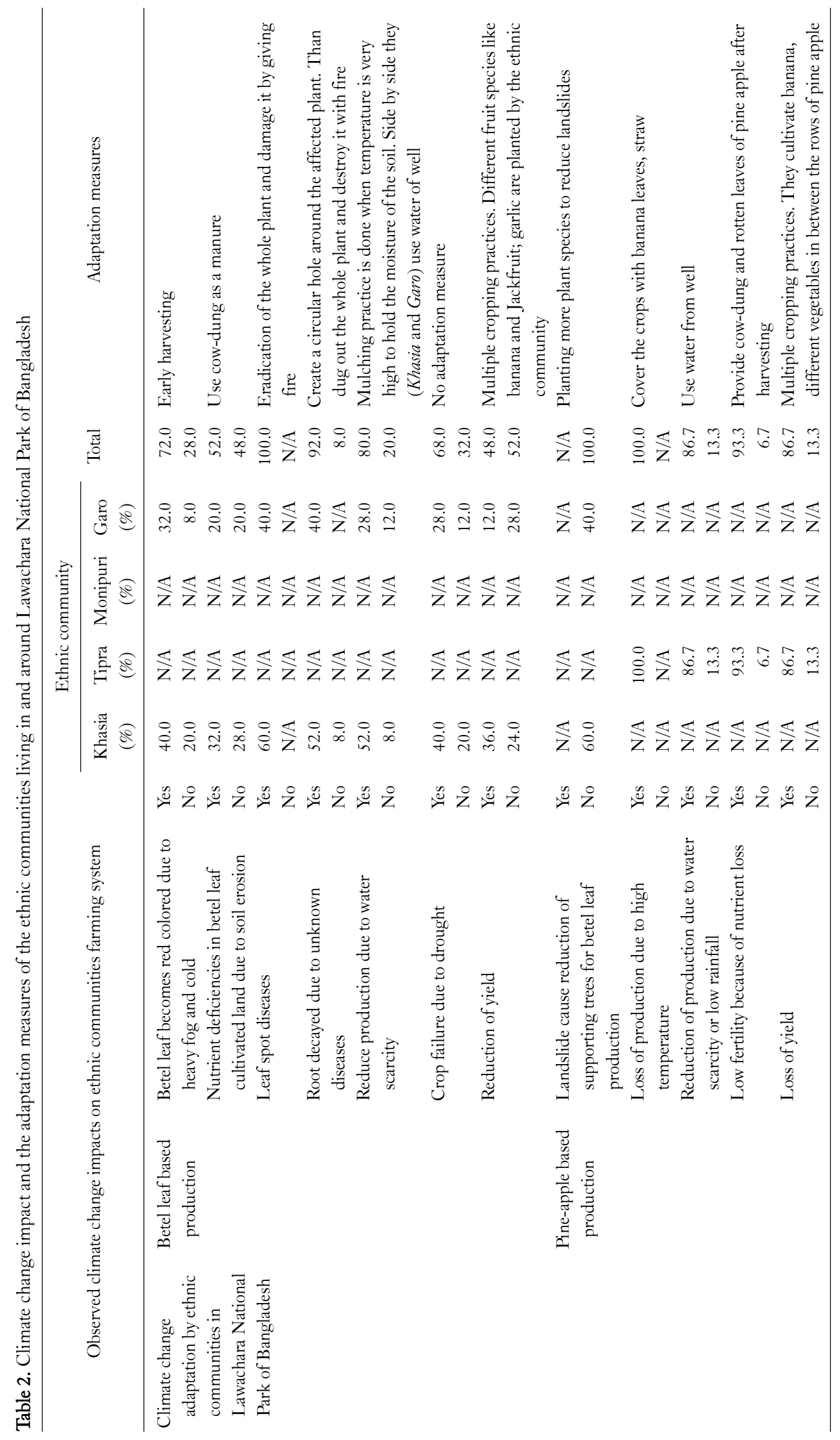




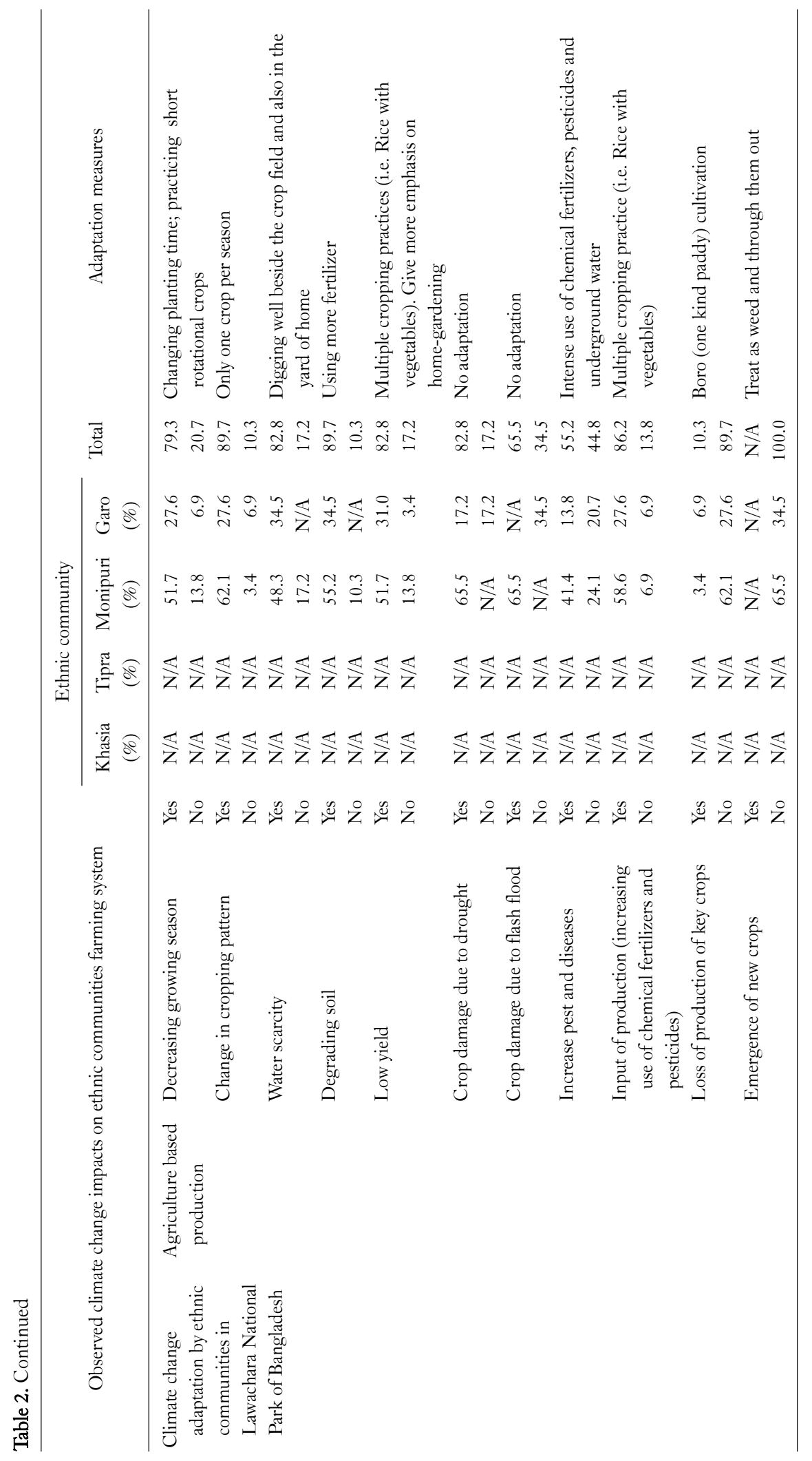




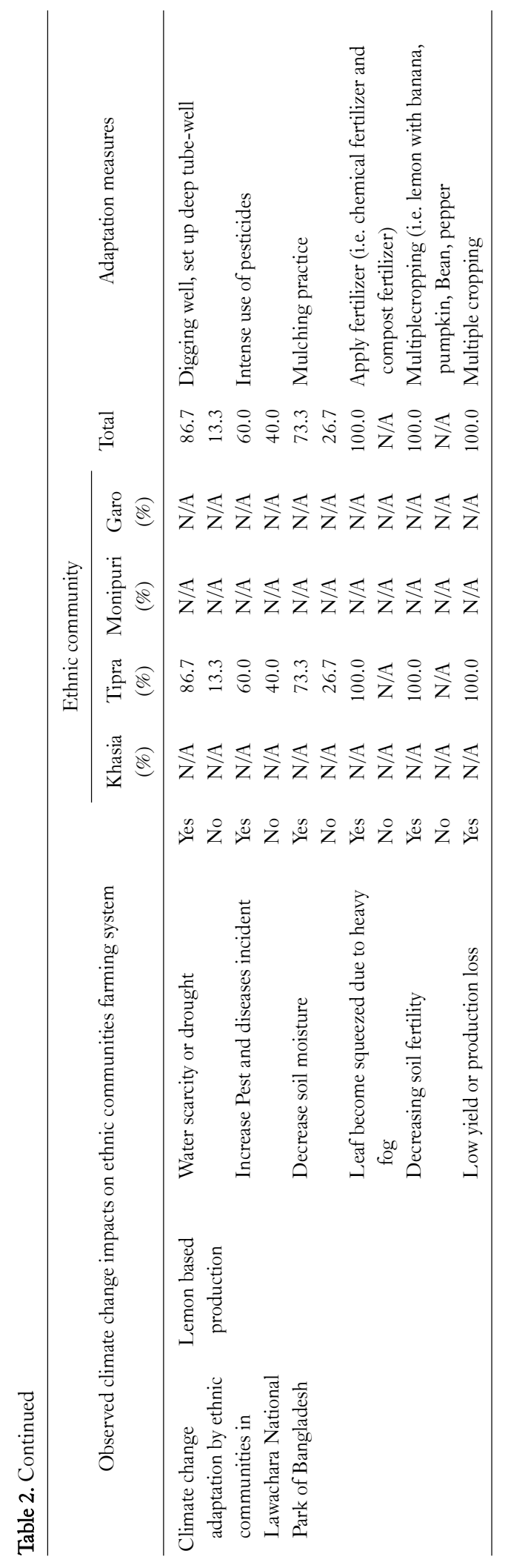

Table 3. Climate change hazards on the production of Pineapple

\begin{tabular}{lccc}
\hline \multirow{2}{*}{ Climate hazards } & \multicolumn{3}{c}{ Component } \\
\cline { 2 - 4 } & Factor 1 & Factor 2 & Factor 3 \\
\hline Increasing temperature & 0.933 & & \\
Low rainfall & & 0.875 & \\
Drought & & 0.767 & \\
Drying of springs & & & 0.941 \\
Soil erosion & 0.706 & & \\
Total variances (\%) & 40.14 & 25.64 & 16.53 \\
Eigen value & 2.01 & 1.65 & 1.22 \\
\hline
\end{tabular}

$\mathrm{KMO}$ value $=0.60$ and only factor loading $\geq 0.50$ has been shown in the tale.

2). During the production period they also use water from the well if there is a heavy water scarcity (Table 2). For saving the pineapple plantation from water scarcity, they use water from well and spring. But these are not sufficient because there are only five well and one spring (Dolu chora) in and around the community. Soil erosion is another problem for pineapple production. Soil erosion cause nutrient loss and ultimately reduce yield of pineapple. To recover this loss tipra people practice multiple cropping (Table 2). They cultivate banana and different vegetables (such as- tomato, peeper) in between the rows of pineapple (Fig. 6E) which provide more income option and also improves their livelihood (Table 3).

\section{Climate change impact on production of lemon and adaptation options}

Lemon production is decreased due to low rainfall and loss of soil moisture and fertility (Table 4). Water deficits during the time of fruit set and early fruit development can cause excessive fruit drop and smaller fruit. Farmers practice multiple cropping and mulching to protect their crops from changing climate, Such as- lemon with banana, lemon with pineapple, lemon with vegetables and also with other fruit species like- mango (Mangifera indica), jackfruit (Artocarpus heterophyllus), papaya (Carica papaya), guava (Psidium guajava), jam (Syzigium grandee), boroi (Zizyphus mauritiana), chapalish (Artocarpus chaplasha) etc (Table 2). More over due to heavy fog and cold the leaves of become squeezed and to overcome this problem the farmers use fertilizer (ash and composed) (Table 4). 
Table 4. Climate change hazards on the production of Lemon

\begin{tabular}{lccc}
\hline \multirow{2}{*}{ Climate hazards } & \multicolumn{3}{c}{ Component } \\
\cline { 2 - 4 } & Factor 1 & Factor 2 & Factor 3 \\
\hline Low rainfall & 0.804 & & \\
Drought & 0.898 & & \\
Drying of springs & 0.748 & & \\
Soil erosion & & 0.609 & \\
Heavy Fog and Cold & & 0.714 & \\
Increasing temperature & & & 0.564 \\
Natural disaster & & & 0.756 \\
Total variances (\%) & 37.76 & 21.25 & 17.90 \\
Eigen value & 1.87 & 1.31 & 1.06 \\
\hline
\end{tabular}

KMO value $=0.57$ and only factor loading $\geq 0.50$ has been shown in the tale.
Table 5. Climate change hazards on the production of Agri crop

\begin{tabular}{lccc}
\hline \multirow{2}{*}{ Climate hazards } & \multicolumn{3}{c}{ Component } \\
\cline { 2 - 4 } & Factor 1 & Factor 2 & Factor 3 \\
\hline Increasing temperature & & 0.778 & \\
High rainfall & 0.914 & & \\
Low rainfall & 0.561 & & \\
Drought & 0.800 & & 0.725 \\
Drying of springs & & & \\
Flash flood & 0.717 & & \\
Natural disaster & & 0.871 & 19.13 \\
Total variances (\%) & 30.71 & 27.57 & 0.89 \\
Eigen value & 1.45 & 1.09 & \\
\hline
\end{tabular}

$\mathrm{KMO}$ value $=0.52$ and only factor loading $\geq 0.50$ has been shown in the tale.
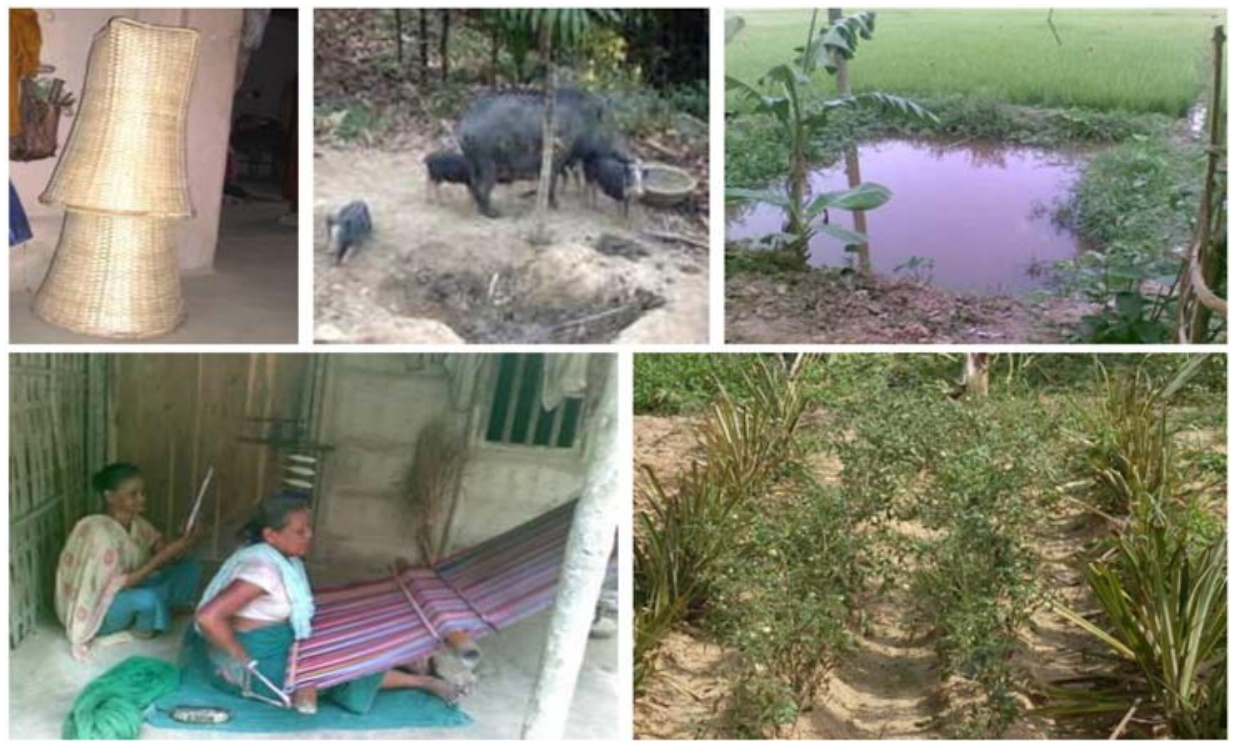

Fig. 6. Clockwise from top left. (A) Handicrafts prepared by Ethnic Community. (B) Bear rearing by ethnic people. (C) Small ditches near agri field. (D) Native weaving as an alternative income source and (E) Pineapple inter-cropping with tomato and peeper by ethnic communities.

\section{Climate change impact on production of paddy and adaptation options}

PCR analysis shows that major climate hazards for agricultural crops of were found precipitation related hazards for Monipuri and Garo community (Table 5). Due to climate change the growing season has been changed and the cropping pattern has also been changed. A new variety of rice (Boro) is practiced now-a day but the production is far below then those varieties (Aus, Amon). According to the farmer it was found that though the hybrid verities are high yielding but less resistant to climatic hazards. According to the Monipuri and Garo community water scarcity, degrading soil, crop damage due to drought, flash flood, increase pest and diseases and input of production (increasing use of chemical fertilizers and pesticides) are the major climatic change impact on agriculture production. Moreover yield of agri crop also reduce due to climate change impact. During drought they use this water in nearby agri field as well as in HG (home garder) as well as dug small ditches beside agri field (Fig. 6D). They also dug small pond in their yard. During data collection small pond was observed in every home yard. To recover crop damage by climate change impact and to ensure food security, they change 
their cropping pattern (Table 2). Among all the studied ethnic community, HG of Monipuri was found very rich (Table 5, Fig. 6D).

\section{Diversifying the income and livelihoods to face cli- mate change impact}

The study shows that when the impact of climate change narrows down the scope of traditional livelihoods of the ethnic communities than they search for alternatives. To adapt with the adverse climatic condition, they give first priority to making the existing livelihoods like agriculture, betel leaf, and pineapple and lemon cultivation more resilient. The second priority is to seek alternative livelihoods like income generation from the available resources and opportunities. For this they collect more forest resource. Besides this, wild boar rearing, net weaving, making handicrafts are the diversified the livelihood options to reduce the potential risks due to climate change and its impact (Fig. 6A, B, C, E, Table 2).

\section{Discussion}

Ethnic communities of Lawachara National Park have distinct culture, livelihood activities, farming practice and ecosystem. They (i.e. Khasia, Monipuri, Garo and Tipra people) identified increase temperature, erratic rainfall, drought, drying of spring and flash flood as major climate hazards. Among these hazards erratic rainfall was the foremost climate hazard for khasia, Tipra and Garo community (living in hills area) whereas flash flood was the dominant hazard for Monipuri community (living in flat land) which these affect their income source highly. Similar findings have been found by Maleya Foundation (2009), BAU (1993) and DoE (2007) and they have mentioned indigenous people Bangladesh from Chittagong Hill tracts (CHTs) facing several climate induced problem like increasing temperature, change in rainfall patterns, increased disease, less production, dried water sources and loss of livelihood.

Among the ethnic communities, Khasia community lives inside the forest and their main livelihood activity is betel leaf cultivation. According to them changing climate highly influenced their betel leaf production. Betel leaf cultivation was highly affected by erratic rainfall, heavy fog and cold.
Due to this changing situation betel leaf production decrease as for good growth of betel leaf, it requires neither too much nor too little rainfall. Besides, betel leaf became red colored due to heavy fog and cold. Harrington et al. (2001) mentioned that betel leaves may change color or become thicker due to climate change. Another disease utram was also found. Due to this infected leaf spot occur and leaves dry then the vine dies. This disease occurs due to intense high rainfall and humidity. Saha and Azam (2004) also found similar diseases during their study period. Besides, root decayed diseases also found in the betel leaf garden and the plant dies finally. This disease also occur die to high rainfall. The rainfall data of Meteorological department also shows increasing trend of rainfall.

Tipra community lives outside the LNP. Their main farming practices are pineapple and lemon cultivation. According to the Tipra community pineapple production are threatened by low rainfall during fruiting time and drying of spring. Although low rainfall or dry environment is favorable for pineapple production (Bartholomew et al. 2003) but before fruiting times this need good amount of water. Unfortunately pineapple plantation didn't get enough water during that crucial time due to unavailability of rainfall and drying of spring. Soil erosion is another problem for pineapple production. Soil erosion cause nutrient loss and ultimately reduce yield of pineapple. Besides, prolonged droughts and increasing temperature are adversely affecting the growth and yield, claimed by the Tipra community. Bartholomew et al. (2003) also agree with this. Tipra people also told that Pineapple fruits are susceptible to high temperature which reduce yield of pineapple. This phenomenon was also reported by McMahon (2005). Lemon cultivation is another farming practice of Tipra community which is highly affected by low rainfall, drought and natural disaster. Water scarcity or drought reduces production of lemon. Morton and Proebst (2003) also found that Water deficits reduce growth and can reduce yields of lemon. Water deficits during the time of fruit set and early fruit development can cause excessive fruit drop and smaller fruit. Drought also reduces soil moisture which retards growth and yield. Similar findings obtained by Morton and Proebst (2003). On the other hand agriculture is the main farming practice of Monipuri community. Garo community also practiced agriculture. Flash flood, low rainfall and 
drought and soil erosion are the major climatic hazards which highly affect agriculture production.

According to the Monipuri and Garo community water scarcity, degrading soil, crop damage due to drought, flash flood, increase pest and diseases and input of production (increasing use of chemical fertilizers and pesticides) are the major climatic change impact on agriculture production. DoE (2007) also told about agri-crop damage due to flash floods and monsoon floods, crop failure due to drought or water scarcity. BUP (1993) found cropping pattern of agri-crops is highly influenced by climatic condition. Moreover yield of agri crop also reduce due to climate change impact. DoE (2007) found that impacts of observed climate changes are felt most in agriculture sector.

A growing collection of empirical evidence now documents a range of climate-change-attributed changes in biological processes, including phenology (Gordo and Sanz 2005; Menzel et al. 2006) net primary production (Nemani et al. 2003; FAO 2005) and inter-specific interactions (Suttle et al. 2007). Changes in species distributions (Walther et al. 2002; Parmesan 2006; Menéndez 2007) and decrease in soil moisture (Mortsch 2006) have also been observed in the production and livelihood. Changes in temperature and rainfall are creating favorable environments for pests, diseases and invasive species to emerge, spread and encroach on forestlands (Rahman 2007; CARE Nepal 2010). Forests are also subjected to a variety of disturbances that are themselves strongly influenced by climate. Disturbances such as fire, drought, landslides, insect and disease outbreaks, and storms such as hurricanes, windstorms and ice storms influence the composition, structure and function of forests. Depending on future climate scenarios, the potential tropical forest area could shrink by as much as 30 percent or expand by up to 38 percent, a shrinking of the area of tropical forests, particularly of moist tropical forests, would be likely to result in significant species losses (FAO 2001). Climate change will also affect productivity of natural ecosystems (Dahal 2005). This had major significance in the loss of wildlife and plant species, and also in the ecosystem function (Rahman 2009). Ecosystem change will affect Indigenous community. This is because Indigenous people's cultural and religious beliefs strongly connect individual and community health to that of their land. Therefore, any unexpected changes in 'natural' sys- tems, or change in abundance or composition of flora and fauna are likely to impact the well-being of the communities associated with them (Green et al. 2009).

\section{Conclusion}

Climate change is evident in the study areas. The statistical analysis of temperature data from 1989-2009 in Srimangal showed a linear trend of increasing around $0.5^{\circ} \mathrm{C}$, with the increase mostly in the winter period. Ethnic Communities are already experiencing unusual changes in temperature and rainfall patterns. Current and future scenarios of climate change indicate that many of the study areas will face risks and climatic stresses have made sectors such as production and livelihood more vulnerable. There have been huge losses in livelihood assets of communities, particularly among the poor ethnic people. Stresses and shocks are aggravating problems and vulnerability of communities. Impacts were observed contributing to loss of production which has forced many people to do illegal acts and also force people do find some alternative livelihood option. Similarly, changes in water balances have affected land, rural economies and food security. Mal-adaptation practices were clearly observed and found to aggravate further vulnerability to water resources. Other hazards, such as drought, flash flood, soil errosion and hailstorm, also resulted in the loss of natural resources and community assets. However, there is some difference in coping capacity among types of ethnic groups. Garo community was more affected by the hazards compared to Khasia, Monipuri and Tipra community. It was observed that ethnic groups have traditionally developed climate resilience systems like developing safety measures and finding alternatives. This is supported by the analysis that people with higher income, education, knowledge, and adaptation options are less vulnerable than those who are deprived from them. Similarly, coping mechanisms, traditional knowledge and innovations all play an important role in shaping vulnerability. Local knowledge, practices and innovations are important elements for community-based coping and adaptation mechanisms. Coping strategies and adaptation mechanism were limited at Gila Chora except Magur Chora, Dolubari and Baligaon. There is urgent need to undertake steps towards awareness increasing programs regarding future un- 
avoidable impacts of climate change and options to cope with it. However, few existing initiatives are initiatives scattered and limited to conduct long-term planning. The more specific studies on the sectorial basis considering gender, ethnicity and economic conditions of peoples is urgent to validate and document the actual coping options to respond to unavoidable impacts of changing climate. At the national level, there was lack of information, knowledge, and proper database regarding local and regional information, and government plans and strategies to deal with climate change impacts. Information derived from the study demands more in-depth sectoral studies and research that address impacts of climate change on ecosystems and biodiversity -wetlands, forests, land-use change, species composition, and important plants and wildlife. There is also a need to integrate communities' perception and knowledge with climate scenarios development and projections. Moreover, local community perceptions and concerns demand for immediate action on promoting climate-resilient development activities at community level.

\section{References}

Bartholomew DP, Paul RE, Rohrback KG. 2003. The pineapple: botany, production and uses. CABI publishing, Wallingford, UK, pp 1-301.

BAU (Bangladesh Unnayan Parishad). 1993. Socio-Economic Implications of Climate Change for Bangladesh. Briefing Document No. 4: Dhaka-1205, Bangladesh, pp 45.

Boer YD. 2009. Adaptation: A critical part of future action on climate change. Statement at the Congress: Adaptation of Society to Climate Change, pp 30.

CARE Nepal. 2010. Climate Change Impacts on Livelihoods of Poor and Vulnerable Communities and Biodiversity Conservation: A Case Study in Banke, Bardia, Dhading and Rasuwa Districts of Nepal. Strengthened Actions for Governance in Utilization of Natural Resources (SAGUN) Program, CARE, Nepal, pp 64.

Dahal N. 2006. Implications of Climate Change in Nepal: Some Observations and Opportunities. Paper presented at 23rd Warden Seminar, Pokhara, Nepal.

Dahal. 2005. Perceptions of Climate Change in the Himalayas. Teimpo bulletin. http://www.cru.uea.ac.uk/tiempo/newswatch/ feature050910.htm. Accessed 15 Aug 2011.

DoE (Department of Environment). 2007. Climate Change and Bangladesh Government of the people's republic of Bangladesh, pp 24.

FAO. 2001. State of the world forest, pp 181.
FAO. 2005. Adaptation of forest ecosystems and the forest sector to climate change. Forests and Climate Change Working Paper No. 2, Rome, FAO/Swiss Agency for Development and Cooperation.

Gbetibouo GA. 2009. Understanding farmers' perceptions and adaptations to climate change and variability: the case of the limpopo basin, South Africa. IFPRI Discussion Paper 00849, pp 52.

Gentleman A, Ahmed A. 2007. Bangladesh mourns as cyclone kills thousands. The Guardian Weekly, London.

Gordo O, Sanz JJ. 2005. Phenology and climate change: a long-term study in a Mediterranean locality. Oecologia 146: 484-495.

Green D, Jackson S, Morrison J. 2009. Risks from climate change to indigenous communities in the tropical North of Australia. Department of Climate Change and Energy Efficiency: Canberra, pp 194.

Green D, Raygorodetsky G. 2010. Indigenous knowledge of a changing climate. Climatic Change 100: 239-242.

Harrington R, Fleming RA, Woiwod IP. 2001. Climate change impacts on insect management and conservation in temperate regions: can they be predicted? Agri For Entom 3: 233-240.

IPCC. 2007. Climate change 2007: impacts, adaptation and vulnerability. Contribution of Working Group II to the Fourth Assessment Report of the IPCC. Cambridge University Press, Cambridge, UK.

Kates RW. 2000. Cautionary tales: adaptation and the global poor. Clim Change 45: 5-17.

Maleya Foundation. 2009. Indigenous Peoples' Mitigation and Adaptation: The Chittagong Hill Tracts, Bangladesh. Proceedings on the conference on Climate Change and Indigenous Peoples, Bali, Indonesia.

McMahon G. 2005. Pineapple. Fact Sheet (FF11), Department of primary industry, fisheries and mines. Crops, Forestry and Horticulture Division, Australia, pp 2.

Menéndez R. 2007. How are insects responding to global warming? Tijdschrift voor Entomologie 150: 355-365.

Menzel A, Sparks TH, Estrella N, Koch E, Aasa A, Ahas R, Alm-kübler K, Bissolli P, Braslavská O, Briede A, Chmielewski FM, Crepinsek Z, Curnel Y, Dahl A, Defila C, Donnelly A, Filella Y, Jatczak K, Mage F, Mestre A, Nordli O, Peñuelas J, Pirinen P, Remi ová V, Scheifinger H, Striz M, Susnik A, Van vliet AJH, Wielgolaski FE, Zach S, Zust A. 2006. European phenological response to climate change matches the warming pattern. Global Change Biol 12: 1969-1976.

Mollah AR, Kundu DK. 2004. Site-Level Field Appraisal for Protected Area Co-Management: Lawachara National Park. Nature Conservation Management (NACOM), Bangladesh.

Morton A, Proebst D. 2003. Organic Citrus Resource Guide. Soil and Health Association of NZ Inc. and Bio Dynamic Association in NZ Inc, pp 58.

Mortsch LD. 2006. Impact of climate change on agriculture, for- 
estry and wetlands. In: Climate change and managed ecosystems, Taylor and Francis. (Bhatti J, Lal R, Apps M, Price M, eds). CRC Press, Boca Raton, FL, US, pp 45-67.

Nemani RR, Keeling CD, Hashimoto H, Jolly WM, Piper SC, Tucker CJ, Myneni RB, Running SW. 2003. Climate-driven increases in global terrestrial net primary production from 1982 to 1999. Sci 300: 1560-1563.

Nobel ASAK. 2009. Climate change adaptation and mitigation through community based agroforestry: evidence from in and around protected areas of Bangladesh. MSc thesis. Department of Forestry and Environmental Science, Shahjalal university of Science and Technology, Sylhet-3114, Bangladesh, pp 123.

NSP. 2006. Management plans for Lawachara National Park. Nishorgo Support Project: Dhaka, Bangladesh.

Olsson P, Folke C, Berkes F. 2004. Adaptive co-management for building resilience in social- ecological systems. Environ Manage 341: 75-90.

Orlove B, Roncoli C, Kabugo M, Majugu A. 2010. Indigenous climate knowledge in southern Uganda: the multiple components of a dynamic regional system. Clim Change 100: 243-265.

Parmesan C. 2006. Ecological and evolutionary responses to recent climate change. Annu Rev Ecol Evol Sys 37: 637-669.

Pender JS. 2008. What Is Climate Change? And How It Will Effect Bangladesh. Briefing Paper. (3rd Draft). Rajshahi, Bangladesh: Church of Bangladesh Social Development Programme.

Rahman MM. 2009. Impact of forest fragmentation on biodiversity. The Daily Star.

Rahman N. 2007. Bangladesh: The First Major Victim of Climate
Change. Star Week Mag 6: 235.

Raut A. 2006. Climate Change Impacts on Nepal. A Bulletin on Change and Development (Special issue on Nepal), 60.

Regmi BR, Adhikari A. 2007. Climate Risk and Vulnerability in Nepal. Country Case Study. Human Development Report 2007/2008 Fighting Climate Change: Human Solidarity in a Divided World. Human Development Report Office Occasional Paper UNDP.

Saha N, Azam MA. 2004. The indigenous hill-farming system of khasia tribes in moulvibazar district of Bangladesh: status and impacts. Small-scale For Eco Manage Pol 3: 273-281.

Sapkota TB, Aryal KP, Tamang BB, Regmi BR. 2006. Enhancing Benefits to Small and Marginal Farmers by Linking Biodiversity to its Niche Market: Findings of the Baseline.

Selvaraju R, Subbiah AR, Baas S, Juergens I. 2006. Livelihood adaptation to climate variability and change in drought prone areas of Bangladesh: Developing institutions and options. Asian Disaster Preparedness Centre, Food and Agriculture Organization of the United Nations, Rome.

Shaw R, Uy N, Baumwoll J. 2008. Indigenous Knowledge for Disaster Risk Reduction: Good Practices and Lessons Learned from Experiences in the Asia-Pacific Region.

Suttle KB, Thomsen MA, Power ME. 2007. Species interactions reverse grassland response to changing climate. Sci 315: 640642.

Walther G, Post E, Convey P, Mensel A, Parmesan C, Beebee TJC, Fromentin J, Hoegh-Guldberg O, Bairlein F. 2002. Ecological responses to recent climate change. Nat 416: 389395. 